\title{
Multiple intelligences and their representation in the EFL young learners' textbooks
}

\author{
Estaji, Masoomeh $\bowtie$ \\ Allameh Tabataba'i University, Iran (mestaji74@gmail.com) \\ Nafisi, Mahdieh \\ Allameh Tabataba'i University, Iran (m_nafissy@yahoo.com)
}

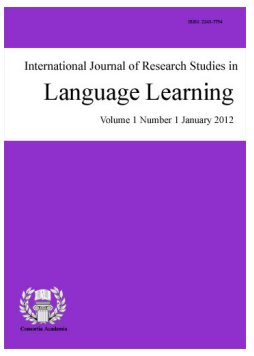

ISSN: 2243-7754 Online ISSN: 2243-7762

OPEN ACCESS

\section{Abstract}

This study was set out with the aim of investigating the extent to which young learners' textbooks reflect and engage multiple intelligences (MI). Furthermore, the current study considered the frequency with which each type of intelligences was presented in young learners' textbooks at four different levels. In particular, it was an attempt to assess the strengths and weaknesses of the currently used books to determine whether the books should be reconstructed to boost MI varieties in the content and to what extent teachers are required to utilize supplementary materials to cover the deficiencies. To this end, a multiple intelligences checklist was developed, based on the framework of the Theory of Multiple Intelligences, to examine the selected textbook in relation to different intelligences as reflected through various activities and tasks. Accordingly, eight textbooks which are currently taught at a language institute young learners' department have been analyzed according to the aforementioned MI checklist. Careful analysis of the selected textbooks revealed that the intelligence profile of these textbooks is primarily verbal/ linguistic. Naturalistic intelligence is recognized as the least intelligence type provided only at intermediate and advanced levels textbooks, and no example of spiritual and existential intelligences was found. However, a fair percentage of distribution for the remaining intelligence types was reported. Pedagogically, the findings of the study hold the implication that policy makers, administrators, and materials developers especially those involved in developing materials for EFL young learners, consider the necessity of applying all intelligence types in designing young EFL learners' textbooks.

Keywords: multiple intelligences; textbook analysis; young learners; tasks and activities 


\section{Multiple intelligences and their representation in the EFL young learners' textbooks}

\section{Introduction}

An investigation of the textbooks especially young learners' textbooks is essential, because textbooks are the most essential resources used by the teachers in language classrooms; moreover, textbooks play an intermediary role in conveying curriculum objectives to students through the help of the teachers. In addition, multi-aged, heterogeneous, individual and diverse classrooms with diversely intelligent students demand teachers to adapt their teaching to meet the challenges of diverse students (Chapman, 1993). However, the traditional view of intelligence and IQ tests have been questioned because they view intelligence as a single construct and individuals as having a single quantifiable intelligence (Campbell, Campbell \& Dickinson, 1996/1999). According to Gardner (1983), students possess different intelligences and textbooks should be designed to represent all varied intelligences to meet all the students' needs.

In considering the underlying concept of MI theory, Gardner (1993) stated that human cognitive competence is better described in terms of a set of abilities, talents or mental skills, which we call "intelligences", and he added that "individuals possess each of these skills to some extent; individuals differ in the degree of skill and in the nature of their combination" (cited by Kırkgöz, 2010). Gardner's theory of Multiple Intelligences introduces human intelligence as eight different categories namely logical, linguistic, spatial, musical, bodily-kinesthetic, interpersonal, intrapersonal, and naturalist intelligences. Gardner searches for a picture of individual ability which is more than the scope of traditional IQ results, thus defining intelligence as "the ability to solve problems and create products, that are valued in one or more cultural or community settings" (Gardner, 1983, p. 7). Gardner's theory and perspective reveal that MI can have a significant impact not only on the design of the foreign language curriculum but also on the design of textbook materials.

Thus far, many studies have been done to analyze the textbooks from different perspectives, such as the study conducted by Litz (2005), who determined the overall pedagogical value and suitability of the book toward a specific language program in Korea. Besides, in a study conducted by Kırkgöz (2010), the researcher has examined five English textbooks in relation to different intelligences, as reflected through the different activities and tasks in order to find out the extent to which the locally-produced EFL textbooks cater for different intelligence types. Moreover, in another study done by Kırkgöz (2009), in which the researcher evaluated the English textbooks for young learners of English in Turkey, she suggested that such evaluation of textbooks should be done on a regular basis to give further insights into the future revision and/or designing of the textbooks for the young learners of English.

Despite the aforementioned studies, limited researches have been carried out in the context of young learners' learning a second language, and most often researchers ignored the representation of multiple intelligences in the young learners' textbooks and the materials. This study can be considered significant in a number of ways. Firstly, it presents a better understanding of the application of MI Theory in the field of materials development and syllabus design by analyzing the young learners' ELT course books and determining their application of various intelligences as proposed by MI theory. Secondly, the findings of this study can reveal to what extent MI Theory is applied in the Iranian young learners' course books; further, the most and least dominant intelligences in the young learners' textbooks can be identified. Thirdly, this study is expected to raise the awareness of teachers, textbook writers, and syllabus designers as to the application of MI Theory in materials development, adaptation, and evaluation specifically, and in language teaching and learning in general. Finally, this awareness building and development can result in improvement in teaching and learning English to children or young learners, as it does to adults.

Therefore, teachers are required to analyze the materials and textbooks in terms of MI Theory in order to 
identify whether the young learners' textbooks address and develop the learners' intelligence profiles. To this end, the present study focuses on the application and representation of the MI Theory in the Iranian EFL context by analyzing the young learners' textbooks at four proficiency levels.

\section{Review of the Related Literature}

\subsection{The Theory of Multiple Intelligences}

Intelligence is traditionally considered as a real, single, measurable, inborn and unchangeable entity. It is traditionally believed to determine our material success (Jarvis, 2005). Intelligence is defined by many as the inborn ability that helps some learn better. This view assumes that intelligence is a fixed construct which doesn't change after age five (Williams \& Burden, 1997). Resistance to the idea of the existence of one and only one intelligences continued and different theory were proposed that opposed this tradition (Stobart, 2008). Different scholars have tried to divide the general intelligence into specific intelligences (e.g., Cattell, 1963; Gardner, 1983, 1993; Sternberg, 1988; Thorndike, 1920). These different intelligences were all similar to general intelligence but distinct from it (cited in Mayer \& Geher, 1996). Two theories were introduced, one was the theory of Multiple Intelligences and the other was the theory of Successful Intelligence.

Since our concern in this research is MI and its effect on the textbooks, the Multiple Intelligences theory is only reviewed and focused. Gardner's theory of multiple intelligences (1983) changed the theory and debated the conventional perspectives of intelligence (Stobart, 2008). Instead of viewing intelligence as a unitary concept, Gardner (1983) views it as different kinds of intelligences (Williams \& Burden, 1997). According to Jarvis (2005), Gardner paid attention to a full range of learner's mental abilities. He questioned the usefulness of general intelligence and proposed a modular approach.

In favor of this view, Sauer (1998) holds that the commonality of Gardner's multiple intelligence theory in education led many teachers to take it as a basis from which to promote curriculum, syllabus and methodology (as cited in Wu \& Alrabha, 2009). Gardner believes that there are seven unique intelligences, not one intelligence with different elements (Illeris, 2008). Following seven independent intelligences were identified by Gardner (1983):

1. Linguistic Intelligence (word smart): According to Gardner, linguistic intelligence is the ability to think in words and to use language to express and appreciate complex meanings. Linguistic intelligence allows us to understand the order and meaning of words and to apply meta-linguistic skills to reflect on our use of language. Linguistic intelligence is the most widely shared human competence and is evident in poets, novelists, journalists, and effective public speakers. Young adults with this kind of intelligence enjoy writing, reading, telling stories or doing crossword puzzles.

2. Spatial Intelligence (Picture Smart): is the ability to think in three dimensions. Core capacities include mental imagery, spatial reasoning, image manipulation, graphic and artistic skills, and an active imagination. Gardner (1983) states, people with a high spatial intelligence perceive the visual world accurately, to perform transformations and modifications upon one's initial perceptions, and to be able to re-create aspects of one's initial perceptions, even in the absence of relevant physical stimuli.

3. Logical-Mathematical Intelligence (Number/Reasoning Smart): is the ability to calculate, quantify, consider propositions and hypotheses, and carry out complete mathematical operations. It enables us to perceive relationships and connections and to use abstract, symbolic thought; sequential reasoning skills; and inductive and deductive thinking patterns.

4. Musical Intelligence (Musical Smart): is the ability to recognize and produce music. They are capable of perceiving, transforming and expressing musical forms (Armstrong, 2000). Young adults with this kind of intelligence are usually singing or drumming to themselves. They are usually quite aware of sounds others 
may miss.

5. Bodily-Kinesthetic Intelligence (Body Smart): is having a well-coordinated body and understanding the world through body. People who possess bodily intelligence are able to do complex and delicate movements. They are successful in using their body for expressing feelings and using their hands for producing things (Armstrong, 2000).

6. Interpersonal Intelligence (People Smart): is the ability to work well with people. It is the ability to understand people's emotions, feelings and motives. It is the ability to perceive different moods, intentions, motivations, and feelings of other people and sensitivity toward others facial expressions, voice, and gestures (Armstrong, 2000).

7. Intra-personal Intelligence (Self Smart): is the capacity to understand oneself and one's thoughts and feelings, and to use such knowledge in planning and directing one's life. Intra-personal intelligence involves not only an appreciation of the self, but also of the human condition.

Later, in 1999, he added a number of other intelligences to these 7 categories. He states that there might also be other intelligences that possibly will be added to the list and some of these identified intelligences may no longer be qualified to be called intelligence. These new intelligences include:

1. Naturalist Intelligence (Nature Smart): is the ability to distinguish patterns in nature.

2. Existentialist Intelligence: is the concern with ultimate issues. It is sensitivity and capacity to deal with deep questions about human existence, such as the meaning of life, and why do we die.

3. Spiritual Intelligence: involves a concern with cosmic issues and the recognition of the spiritual as the achievement of a state of being (Sternberg, 2004).

Gardner believes that each person is well-equipped with some intelligence, but less equipped with others. It is proposed that all people have all the eight intelligences but to different degrees. These intelligences are in a permanent interaction with each other. All these intelligences also can be developed if encouraged, enriched, and instructed (Armstrong, 2000).

\subsection{The Application of Multiple Intelligences Theory in Education}

The literature of MI Theory in the field of education entails information as to the application of MI theory in classrooms, curriculum and syllabus design, and evaluation and assessment. Moreover, it provides recommendations for teachers, students, textbook writers, curriculum developers, and syllabus designers. According to Chen, Moran, and Gardner (2009),

MI Theory can be a very helpful "vehicle for broadening the remit of education: to include subjects that address the several intelligences and ways of thinking, as well as teaching methods that speak to individual differences, and assessments that go beyond standard, short-answer language-and-logic instruments”. (p. 14)

The application of MI Theory has led to the development of new assessment methods; the formation of MI based curriculum and instruction, as well as positive experiences and close connection with students and their parents (Hoerr, 2000). Likewise, educators and teachers have claimed that the application of MI Theory in education and classrooms will definitely have positive effects as to the learners' interest, motivation, and success. More importantly, implementing MI Theory in curriculum and syllabus design has been found to improve and develop teaching practices and assessment techniques. 


\subsection{Multiple Intelligences Theory and Its Role in the ELT Curriculum}

The application of MI Theory in ELT can be considered invaluable for both teachers and students as to the curriculum design, instructional strategies, materials and textbooks utilized in language teaching and learning. In particular, the theory of MI has had a significant impact not only on the design of the foreign language curriculum but also on the design of textbook materials. Moreover, MI-inspired curriculum can improve academic performance and raise the students' motivation and interaction in the classroom. In the study which involved the evaluation of activities in a textbook according to the MI Theory, Ferro (2004) revealed that MI Theory is very practical in encouraging the creation of activities according to the different intelligence types and enhancing the learning experience of the students.

It is possible that the integration of an MI curriculum with the textbooks can resolve some of the problems that the field of education and ELT may encounter. However, in some EFL contexts like Iran, the integration of the theory of MI into the ELT (English Language Teaching) curriculum is quite a recent phenomenon which requires extensive investigation through textbook analysis and evaluation. It's important to note that Gardner's MI theory was used as a theoretical framework assessing the availability, presence, and representation of MI structured tasks in those particular textbooks developed for young EFL learners.

\subsection{Previous Studies on MI and ELT Textbooks}

Upon review of the literature available in the area of textbook evaluation, some studies have attempted to evaluate textbooks in the light of MI Theory. For instance, Kırkgöz (2010) investigated the extent to which English textbooks which are locally designed for primary education in Turkish state schools reflect Multiple Intelligences. The researcher examined each textbook in relation to different intelligences as reflected through different activities and tasks. The obtained results indicated that the intelligence profile of English textbooks is predominantly verbal/linguistic and visual/spatial. Naturalistic intelligence is identified as the least intelligence type that is catered only in grade 4 and grade 5 textbooks, and no example of spiritual/existential intelligence was found. Also, a fair percentage of distribution for the remaining intelligence types was perceived.

Furthermore, Palmberg (2001), reports a textbook evaluation study conducted at Abo Akademi University in Finland by a group of student teachers, who participated in an EFL methodology course. The analysis of the course book (Bricks1) shows that $97 \%$ of the 300 exercises were catered for verbal/linguistic, $76 \%$ intrapersonal, $25 \%$ interpersonal, $8 \%$ logical/mathematical, 5\% bodily/kinesthetic, 5\% [spatial/visual], 3\% naturalist, $2 \%$ musical and $0 \%$ existentialist. The second major finding of this study is that the textbook intelligence profile reflects the writer's personal profile and teachers' learning styles as well as teachers' own preferences. Palmberg (2001) states that once teachers choose a course book to base their courses, "they must be able to assess how well the intelligence profile of the selected course book coincides with the majority of intelligence profiles found for that learner group" (Palmberg, 2001, p. 3). He likewise adds that in order to encourage students and to make the learning environment better for everyone, teacher should bear in mind that learners are different and learn differently.

In a similar vein, Nasiri, Ketabi, and Dastjerdi (2012) did similar investigation in which they investigated the extent to which English textbooks which are locally designed for primary education in Iranian state schools reflect Multiple Intelligences. It has been reported that the intelligence profile of English textbooks is predominantly logical-mathematical and visual/spatial. Musical and Verbal/Linguistic intelligence are identified as the least intelligence type, and no example of Natural, interpersonal and intrapersonal intelligence was found.

Moreover, Snider (2001) evaluates ten first-year college German textbooks. His aim was to determine the types of activities that were presented and to find out how the activities engaged multiple intelligences in learners. Snider finds forty-one types of activities. He further indicates that, "only eleven engage intelligences other than verbal/linguistic" (p.133). The study provides suggestions to adapt activities which enhance all the 
intelligences in learners. Snider (2001) draws our attention to the predominant activity types, which primarily enhance the verbal/linguistic intelligence, to demonstrate how changes can be made to enhance more intelligence.

Finally, Botelho (2003) evaluates six books (American Headway 2, Explorations 1, Gateways 1, Go for it! 4, 'New Interchange 1, and Passages 1) in order to find the dominant intelligences in the activities. The study reveals that verbal/linguistic, intrapersonal, spatial/visual and interpersonal are the main intelligences in the six books. According to the analysis in this study, verbal/linguistic and intrapersonal are presented in $100 \%$ of the activities; spatial/visual was presented in $90.08 \%$; and interpersonal are presented $76.07 \%$ of all the activities in the six books. The less common intelligences are: logical/mathematical, bodily/kinesthetic, musical, naturalist and existential. The results show that activities that enhance more intelligence are usually games, extra activities and a combination of two skills such as listening/speaking.

Since limited researches have been done concerning young learners' learning a second language and restricted analysis of the textbooks provided for the young learners, in the current study, the researcher intends to investigate whether the textbooks designed for the young learners, taught in one of the most well-known institutes in Iran, consider the role of multiple intelligences and whether these textbooks help the students to enhance their Multiple Intelligences.

\subsection{Purpose of the Study}

Armstrong (2000) stated that given appropriate instruction, most individuals have the capacity to develop each of the intelligences to an adequate level of competency. In terms of English language textbooks, however, few books have been designed and published to represent the principles of MI theory in language teaching domain. More importantly, no thorough ELT book has been designed to exert MI theory on its content completely though it is crucial that the deigned textbooks address as many of the intelligences as possible in order to cater for the needs of the students. Similarly, no investigation has yet evaluated young learners' textbooks in the light of MI theory. Therefore, since textbooks have a central role in ELT classrooms and it's almost the only source used by teachers during teaching, this study aims to investigate how young learners' ELT textbooks reflect MI and whether the textbooks designed for the young learners consider the role of MI or not. Therefore, the study seeks to respond the following questions:

1. Are the young learners' English textbooks different in terms of applying different kinds of intelligences as proposed in MI theory?

2. If so, what are the most and least dominant intelligences in the young learners' textbooks?

3. To what extent do the young learners' ELT textbooks enhance their multiple intelligences?

\section{Method}

\subsection{Materials}

For the purpose of this study, four young learners textbooks entitled Up and Away in English written by Terence $\mathrm{G}$ Crowther were selected and examined to determine the representation of different intelligences, further, to find out the extent to which each textbook caters for different intelligences as reflected through the activities and the tasks. The selected textbooks are currently taught at a language institute in Iran to the children of different levels of elementary (Primer), pre-intermediate (Step), intermediate (Move), and advanced (Jump). Each level of UP and Away in English entails the student book, workbook, teacher's book and readers. A set of flash cards is also available. The units in the four analyzed textbooks entail the four skills (listening, speaking, reading and writing) as well as grammar, vocabulary, and pronunciation activities and practices which were considered as the unit of data collection. Since these books were designed for children and because of the 
student's age and low level of proficiency, these are the teachers who guide students and ask them to do particular activities in the classroom environment based on teacher's guide supplementary materials. As a result, the teacher's guide has been examined as well. From among each level, two textbooks along with their teacher's guide have been selected to be analyzed according to the MI checklist.

It is important to note that the textbooks were selected through purposive sampling. The rationale for selecting the young learners' textbooks was that they had not been studied in the previous research studies despite being widely taught. These textbooks are published by Oxford University Press. It is worth pinpointing that for identifying the appropriate categories of MIs, particular tasks or activities were focused which represented and intended to cater for different categories of intelligence.

\subsection{Instrumentation: Developing MI Checklist Used as Coding Schemes for the Textbooks}

Materials evaluation involves a careful and professional "activity for all ELT teachers" (McDonough \& Shaw, 1993, p. 63). However, there is a need for a checklist to conduct a systematic evaluation of a textbook (McDonough \& Shaw, 1993). The present study utilized a multiple intelligences (MI) checklist, originally developed by Kırkgöz (2010), which was designed based on the literature review and the framework of the theory of MI (see Gardner, 1983, 1993, 1999) consisting of the definitions of the eight intelligences provided by Armstrong (2000) and a matrix of activities for each of the intelligences (See Appendix). In other words, this checklist was used as a coding scheme for better classifying and evaluating the content of textbooks following MI theory. The coding categories were labeled as: VL for verbal/linguistic; LM for logical/mathematical; SV for spatial/visual; BK for bodily/kinesthetic; $\mathrm{M}$ for musical; IR for interpersonal; IA for intrapersonal and $\mathrm{N}$ for naturalist intelligence. In order to ensure internal consistency or reliability of the items presented in the checklist, two instructors evaluated and rated the textbooks using the aforementioned checklist. The correlation coefficient between their ratings $(r=0.83)$ revealed that the checklist was a reliable instrument to be used in this study. Moreover, expert opinion was obtained from two other professional EFL instructors who reviewed the textbook evaluation checklist utilized in this study.

\subsection{Data Collection Procedures}

The selected textbooks were carefully examined in relation to different intelligences, as reflected through the activities and the tasks in order to find out the extent to which each textbook caters for different intelligences. In doing so, the type and description of the activity, the elements such as pictures and graphs that were part of the activity, the techniques and the materials required for complementing the activity, and the skills being practiced were considered while determining the intelligences in the activities. The frequency of the occurrences of each of the intelligence in an activity and its relevant percentage were counted in all the textbooks.

In order to categorize an activity to an appropriate intelligence, the first step was to decide which intelligence an exacting task or activity predominantly took into account (Kırkgöz, 2010). For example the activity " color " or " draw " are some actions which were needed to be done by students and are clearly intended to satisfy bodily/kinesthetic intelligence. As a result, it was categorized as a single type of intelligence. However, some activities serve more than one intelligence type. For example the activity "work in pairs, do the puzzle" was categorized as both interpersonal and logical/mathematical intelligences because the first part of the activity explicitly stated that it was intended for pair work and the second part addressed logical intelligence of learners. The process of identifying intelligences in each textbook was carried out independently by the researchers who are pretty familiar with the textbooks' content, the teacher's guide, and the type of tasks or activities required to be performed in the classroom environment. The results obtained were based on the total number of activities in the four textbooks, the sum, and proportion of occurrences of each of the intelligence in all the books.

\subsection{Data Analysis}

Descriptive statistics, using spread sheet Microsoft excel, were used to analyze the data and calculate the 
frequencies of occurrences of the intelligence types for the textbook tasks and activities After each selected textbook was examined according to the checklist of different intelligences, as reflected through the activities and the tasks, the total number of occurrences of each intelligence type in all activities of the textbooks was calculated and the frequencies were obtained which revealed the intelligence profiles of the scrutinized textbooks.

\section{Results}

The results of the young learners' textbook analysis in terms of MI theory, using frequency count descriptive statistics, revealed the following distribution of intelligences in the textbooks:

\section{Table 1}

Distribution of intelligences in the young learners' textbooks by frequencies

\begin{tabular}{lccccccccc}
\hline $\begin{array}{l}\text { Textbooks } \\
\text { (Levels) }\end{array}$ & $\begin{array}{c}\text { Verbal/ } \\
\text { Linguistic }\end{array}$ & $\begin{array}{l}\text { Visual// } \\
\text { Spatial }\end{array}$ & $\begin{array}{l}\text { Logical/ } \\
\text { Mathematical Kinesthetic }\end{array}$ & \multicolumn{2}{c}{ Bodily/ Musical Inter } & \multicolumn{2}{c}{ Intra } & Naturalistic total \\
persol personal & f \\
\hline Elementary & 146 & 143 & 72 & 48 & 9 & 39 & - & - & 457 \\
(Primer) & 31.94 & 31.29 & 15.75 & 10.50 & 1.96 & 8.53 & & & 100 \\
\hline Pre Intermediate & 223 & 48 & 62 & 27 & 6 & 56 & 12 & - & 434 \\
(Step) & 51.38 & 11.05 & 14.28 & 6.22 & 1.38 & 12.90 & 2.76 & & 100 \\
\hline Intermediate & 196 & 11 & 34 & - & 6 & 27 & 10 & 5 & 287 \\
(Move) & 68.29 & 3.83 & 11.84 & & 2.09 & 9.40 & 3.48 & 1.74 & 100 \\
\hline Advanced & 166 & 23 & 49 & 9 & 20 & 76 & 25 & 2 & 370 \\
(Jump) & 44.86 & 6.21 & 13.24 & 2.43 & 5.40 & 20.54 & 6.75 & 0.54 & 100 \\
\hline
\end{tabular}

Table 1 displays the distribution of intelligences in the young learners' textbooks at four levels of elementary, pre-intermediate, intermediate, and advanced. In the above table, the number of activities which represent the particular type of intelligence along with their frequencies is represented. As can be seen in this table, the elementary and pre-intermediate levels catered for different intelligence types in total more than the high proficiency levels. However, verbal/linguistic intelligence was the most dominant type in the young learners' textbooks. Between 31.94 to $68.29 \%$ of the activities focused on the verbal/linguistic learners. A reasonable justification for this trend is the fact that language textbook should encompass activities highly focusing on the linguistic intelligence type. Thus, the ratio of linguistic intelligence as the most dominant intelligence type even in the young learners' textbooks is logical and expected.

Notably, there was a difference between elementary levels and the other levels in terms of the second most frequently addressed intelligence. While elementary levels textbook catered for the visual/ spatial as the second most frequently addressed intelligence type (31.29\%), in the other two levels (pre-intermediate and intermediate) the second most frequently addressed intelligence was the logical/mathematical type. Between 11.84 to $14.28 \%$ of the activities in these two levels represented logical/mathematical intelligence types. However, at advanced levels, the second most frequently addressed intelligence type was interpersonal. More than $20 \%$ of the activities at this level catered for the interpersonal learners.

The third most frequently addressed intelligence type in the elementary level textbooks was logical/mathematical $(15.75 \%)$, followed by bodily/kinesthetic $(10.50 \%)$, interpersonal $(8.53 \%)$, and musical $(1.96 \%)$ intelligence. The third most frequently used intelligence type in the textbooks of the two levels of pre-intermediate and intermediate was interpersonal $(12.90 \%$ and $9.40 \%)$, followed by Visual/spatial $(11.05 \%$ and $3.83 \%$ ), while at pre-intermediate level the next most frequent intelligence type was bodily/kinesthetic with $6.22 \%$. It's important to note that the intermediate level does not represent any instances of bodily/kinesthetic intelligence type. Afterward, the two levels of pre-intermediate and intermediate represented intrapersonal $(2.76 \%$ and $3.48 \%)$, musical $(1.38 \%$ and $2.09 \%)$, and finally naturalistic intelligence with intermediate level textbooks representing $1.74 \%$ of it while pre-intermediate level did not represent it at all. On the other hand, the third most frequently noticed intelligence type at advanced levels, just like elementary levels, was 
Multiple intelligences and their representation in the EFL young learners' textbooks

logical/mathematical (13.24\%), followed by intrapersonal (6.75\%), visual/spatial $(6.21 \%)$, musical $(5.40 \%)$, bodily/kinesthetic $(2.43 \%)$, and naturalistic $(0.54 \%)$ intelligence type.

All in all, it can be concluded that verbal/linguistic, logical/mathematical, and interpersonal intelligence types were among the most frequently addressed intelligence types through all levels. As can be vividly revealed in table 1, naturalistic intelligence was found to be the least catered for intelligence type which was represented only at intermediate and advanced level textbooks. In all different levels of these textbooks, there was no sign of neither existentialist nor spiritual intelligence types which means that no activities were found that revolved around these two intelligence types.

\section{Discussions}

Since textbooks are the most crucial and important resources used by the teachers in language classrooms, playing a mediator role in conveying the curriculum objectives to the students through the help of the teachers, the analysis of the textbooks especially the investigation of the young learners' textbooks seems to be essential. As it was indicated in many studies, like Saricaoglu and Arikan (2009), Bas and Beyhan (2010), multiple intelligences play a crucial role in students' and teachers' success by having a significant impact not only on the design of the foreign language curriculum but also on the design of textbook materials. Furthermore, Darling-Hammond, Austin, Lit, and Martin (2003) asserted that, MI theory is a way of thinking about how children learn and how best to teach them. The theory provides a way of thinking about how we learn that urges teachers to extend the boundaries of traditional curriculum. Accordingly in designing textbooks and teaching materials, it seems necessary to consider the various types of talents and abilities students bring with them to the learning environment; further, textbook developers needed to put greater emphasis on the variety of skills necessary to succeed in education and learning.

As indicated in the results section, the elementary and pre-intermediate levels cater for different intelligence types more than high proficiency levels at large considering the total percentage. This could be because of the age and low level of learners' proficiency level in the language they are going to learn through these analyzed textbooks. Since at elementary levels students are younger and novice language learners, the textbooks consist of different activities ranging from drawing pictures, listening to the songs, performing some actions such as walking and running to making meanings and concepts clear. Likewise, they may contain more games and activities engaging all the students' potentials for learning a new language. As a result, the textbooks were designed in such a way to engage all the intelligence types of the students and activate them in order to make the process of learning more convenient. Hence, they should not only focus on the linguistic/verbal intelligence due to their low level of proficiency, but also on the other types of activities which are representative of other types of intelligences resulting in high frequency of occurrence of intelligence types at elementary levels.

Similarly, the analysis of the obtained data revealed that each level catered mainly for verbal/linguistic intelligence. This result may be due to the fact that, activities like reading and writing are constantly present in language textbooks, so such a result was rather predictable. Moreover, this outcome seems to be compatible with Kırkgöz's inference (2010), in which the results of the study disclosed that each ELT textbook caters predominantly for the verbal/linguistic intelligence.

On the other hand, the total analysis revealed that, besides verbal/linguistic intelligence which was the most frequent type at all levels, logical/mathematical and interpersonal intelligence types were also among the most frequently addressed intelligence types through all levels. Frequent representation of logical/mathematical in the analyzed textbooks may be due to the fact that related classroom activities are more often in the form of drills and some other activity types such as matching, categorizing, predicting, ordering, etc. This implies the existence of a great deal of logical/mathematical intelligences. Since interpersonal intelligence type was rather represented at high proficiency levels, we can infer that the students were more proficient at intermediate and advanced levels; therefore, they were able to perform communicative activities through lessons more effortlessly. The 
young learners' textbooks entailed plethora of such tasks and activities which were representative of this type of intelligence. This result seems to be in contrast with the result obtained by Nasiri, Ketabi, and Dastjerdi (2012), in a work entitled the analysis of presentation of MI in locally-published ELT textbooks in Iran, in which they suggested that interpersonal intelligence type has no room in the activities of Iranian high school textbooks.

Interestingly just in line with the findings of Kırkgöz (2010) and Tasse (2012), naturalistic intelligence was found to be the least catered for intelligence type which in this study, was represented only at the intermediate and advanced level textbooks. That may be due to the lack of time allocated for the classroom activities especially those required to be performed out of the classroom environment. Moreover, there seems to be very little room for the activities like naturalistic intelligence type. More importantly it was indicated in the findings of the present study that, at all different levels of these textbooks there is no trace of neither existentialist nor spiritual intelligence types.

Finally, it can be interpreted that there existed no balance in the young learners textbooks' activities in terms of the distribution of the intelligence types addressed. However, these findings revealed a reasonable representation of intelligence types through levels. Since at elementary levels students are less proficient and less familiar with the target language, the textbooks embody activities which represent the visual/spatial and bodily/kinesthetic intelligence types, on the other hand as the students get more proficient, experienced, matured, and advanced, the textbooks rather focus on the activities that represent more interpersonal and intrapersonal intelligence types.

\section{Conclusions and Implications}

The present study sought to investigate the representation of multiple intelligences in the young learners' textbooks as reflected through various activities and tasks in order to find out the extent to which the young learner's textbooks represent and cater for different intelligence types. The results revealed that the analyzed textbooks catered predominantly for the verbal/linguistic intelligence, although there was a fair percentage of distribution for other intelligence types as logical/mathematical, interpersonal, and visual/spatial.

It is evident that the textbook writers are required to find ways to challenge and involve all of the intelligence types to fulfill the needs of the learners and to adopt and utilize all of intelligences based on the learners' disciplines, styles, and strategies. According to Armstrong (2000), given appropriate instruction, most individuals have the capacity to develop each of the intelligences to an adequate level of competency, whereas other intelligence types such as musical, bodily/kinesthetic, intrapersonal, and naturalistic seem to require more opportunities to be represented through textbooks, further, require more attention to be paid to.

This study has some implications for teachers, researchers, and textbook developers. Teachers must be aware of individual differences among their students, and textbook developers should have MI theory in their mind while developing new textbooks specially designed for the children and young learners to provide activities, opportunities, and tasks that suit the students' needs according to various types of multiple intelligence. This can be considered as one of the problematic issues in many education systems because students have different intelligences but they are not addressed in classrooms (Altan, 2001). Accordingly, making use of MI Theory in developing materials for the young learners and the students can foster learning and teaching processes, encourage students, and raise their motivation and interest. Adding more variety and intelligences to tasks in the textbooks will further grow teachers' and learners' understanding of what success and educational progress mean in the school setting.

In addition, language policy makers are expected to design programs to raise the learners' level of multiple intelligences and educate learners about the value of these different types of intelligences. Alternatively, English teachers are expected to become well acquainted with the concept to enhance the multiple intelligences of their learners. Material developers are also required to consider techniques which pay more attention to MI factors, leading the learners to more self and other-discovery. It is likely that with such a trend for instructional materials 
to be adaptable to differences and variety of modalities for the various learning styles of students such as linguistic/verbal, logical, musical, spatial, kinesthetic, interpersonal, intrapersonal and naturalist, instructors and textbook writer will commence to create more diversity within textbook activities and tasks which will benefit teachers and students. Employing activities such as simulations, role-plays, discussions, and interpersonal and intrapersonal scenarios would likely fulfill the diverse needs of the students.

Further studies can be carried out by examining and comparing other young learners' course books or textbooks from various perspectives of MI theory while employing more raters in order to get more generalizable results. Moreover, the scope of research can be extended by interviewing teachers, learners, and observing young learners' classes at different institutions to better evaluate, adapt, and design materials which cater for all intelligence types. Finally, future studies can focus on mixed methods research design to better judge the representation of multiple intelligences in the young learners' textbooks.

\section{References:}

Altan, M. Z. (2001). The theory of multiple intelligences: What does it offer EFL Teachers? Modern English Teacher, 10(1), 52-56.

Armstrong, Th. (2000). Multiple intelligences in the classroom. USA: Association for Supervision.

Bas, G., \& Beyhan, O. (2010). Effects of multiple intelligences supported project-based learning on students' achievement levels and attitudes towards English lesson. International Electronic Journal of Elementary Education, 2(3), 365-386.

Botelho, M. (2003). Multiple intelligences theory in English language teaching and analysis of current textbooks, materials, and teachers' perceptions. Unpublished MA thesis. Ohio University, Ohio.

Campbell, L., Campbell, B., \& Dickinson, D. (1996/1999). Teaching and learning through multiple intelligences. Massachusetts: Allyn \& Bacon.

Cattell, R. B. (1963). Theory of fluid and crystallized intelligence: A critical experiment. Journal of Educational Psychology, 54(1), 1-22. http://dx.doi.org/10.1037/h0046743

Chapman, C. (1993). If the shoe fits... How to develop intelligences in the classroom. Glenview: Pearson.

Chen, J. Q., Moran, S., \& Gardner, H. (Eds.). (2009). Multiple intelligences theory around the world. San Francisco, CA: Jossey-Bass Publishers.

Darling-Hammond, L., Austin, K., Lit I., \& Martin, D. (2003). Different Kinds of Smart: Multiple Intelligences. The Learning Classroom, 73-80. Retrieved March 27, 2010, from http://www.learner.org/courses/learning classroom/support/04_mult_intel.pdf

Ferro, M. S. (2004). A Survey of Multiple Intelligences in a College Classroom. Teacher Action Research Project. George Mason University.

Gardner, H. (1983). Frames of mind. New York: Basic Books.

Gardner, H. (1993). Frames of mind: The theory of multiple intelligences. New York: Basic Books.

Gardner, H. (1999). Intelligence reframed. Multiple intelligences for the $21^{\text {st }}$ century. New York: Basic Books.

Hoerr, T. (2000). Becoming a multiple intelligences school. Alexandria, VA: Association for the Supervision and Curriculum Development (ASCD).

Illeris, K. (2008). How we learn: Learning and non-learning in school and beyond. USA: Routledge

Jarvis, M. (2005). The psychology of effective learning and teaching. Cheltenham, UK: Nelson Thornes Ltd.

Kırkgöz, Y. (2009). Evaluating the English textbooks for young learners of English at Turkish primary education. Procedia Social and Behavioral Sciences, 1(1), 79-83. http://dx.doi.org/10.1016/j.sbspro.2009.01.016

Kırkgöz, Y. (2010). Catering for multiple intelligences in locally-published ELT textbooks in Turkey. Procedia Social and Behavioral Sciences, 3(1), 127-130. http://dx.doi.org/10.1016/j.sbspro.2010.07.023

Litz, D. (2005). Textbook evaluation and ELT management: A South Korean case study. Asian EFL Journal, 6(4) $1-53$.

Mayer, J. D., \& Geher, G. (1996). Emotional intelligence and the identification of emotion. Intelligence, 22(2), 89-113. http://dx.doi.org/10.1016/S0160-2896(96)90011-2 
McDonough, J., \& Shaw, C. (1993). Materials and Methods in ELT. Oxford: Blackwell.

Nasiri, M., Ketabi. S., \& Vahid Dastjerdi, H. (2012). Multiple intelligences in locally-published ELT textbooks in Iran. Modern Journal of Applied Linguistics, 4(4), 258-266.

Palmberg, R. (2001). Catering for multiple intelligences in EFL coursebooks. HLT Magazine, January 2002. Retrieved November 9, 2009, from http://www.hltmag.co.uk/jan02/sart6

Saricaoglu, A., \& Arikan, A. (2009). A study of multiple intelligences, Foreign language success and some selected variables. Journal of Theory and Practice in Education, 5(2), 110-122.

Sauer, C. (1998). Developing a survey for multiple intelligences. In J. M. Reid (Ed.), Understanding learning styles in the second language classroom (pp. 100-106). Upper Saddle River, NJ: Prentice Hall Regents.

Snider, D. P. (2001). Multiple intelligences theory and foreign language teaching. Unpublished doctoral dissertation, University of Utah, U.S.A.

Sternberg, R. J. (1988). The triarchic mind: A new theory of human intelligence. New York: Viking.

Sternberg, R. J. (2004). North American approach to intelligence. In R. J. Sternberg (Ed.), International handbook of intelligence (pp. 411-444). UK: Cambridge University Press. http://dx.doi.org/10.1017/CBO9780511616648.016

Stobart, G. (2008). Testing times: The uses and abuses of assessment. USA: Routledge.

Tasse, Y. (2012). Multiple intelligences theory and Iranian textbooks: An analysis. Pan-Pacific Association of Applied Linguistics, 16(1), 73-82.

Thorndike, R. L. (1920). Intelligence and its uses. Harpers' Magazine, 140(4), 227-235.

Williams, M., \& Burden, R. L. (1997). Psychology for language teachers: A social constructivist approach. UK: Cambridge University Press.

Wu, S., \& Alrabah, S. (2009). A cross-cultural study of Taiwanese and Kuwaiti EFL learning styles and multiple intelligences students. Innovations in Education and Teaching International, 46(4), 393-403. http://dx.doi.org/10.1080/14703290903301826

\section{Appendix}

Sample activities addressing various intelligences as represented in the textbooks

\begin{tabular}{|c|c|c|}
\hline Intelligence Type & Capability and Perception & Sample Activities \\
\hline Verbal/Linguistic & $\begin{array}{l}\text { words and language, speak on } \\
\text { a subject, write a speech }\end{array}$ & $\begin{array}{l}\text { Let's talk. Let's write. Write the questions. You want } \\
\text { to make a cake. Write what you need and what you } \\
\text { don't need? Name the game pieces. Say what you do } \\
\text { and what you don't do yourself? }\end{array}$ \\
\hline Logical-Mathematical & $\begin{array}{l}\text { logic and numbers, create a } \\
\text { process }\end{array}$ & $\begin{array}{l}\text { Number the parts. Put the sentences in order. Do you } \\
\text { know any words with two meanings in English? Do the } \\
\text { puzzle. Unscramble the sentences. Choose the right } \\
\text { answer. Recognize the beginning sound of each word. }\end{array}$ \\
\hline Musical & music, sound, rhythm & Let's sing. Listen to the numbers and sing. Chant. \\
\hline Bodily-Kinesthetic & $\begin{array}{l}\text { body movement control, } \\
\text { touch and feel }\end{array}$ & $\begin{array}{l}\text { Clap once for each syllable. Give commands and do the } \\
\text { action. Let's act. Let's play. Walk, run, jump. }\end{array}$ \\
\hline Visual-Spatial & $\begin{array}{l}\text { images and space, design a } \\
\text { table }\end{array}$ & $\begin{array}{l}\text { Draw gifts. Match the sentences. Join the dots to help } \\
\text { the animal find its home. Make the same picture and } \\
\text { color. Listen and draw hands on the clock. }\end{array}$ \\
\hline Interpersonal & $\begin{array}{l}\text { other people's feelings, } \\
\text { communication, team work }\end{array}$ & $\begin{array}{l}\text { Work in pairs, ask and answer. Talk to your family } \\
\text { members and write their opinions. Do you know a } \\
\text { riddle? Ask your friend. Interview your grandparents to } \\
\text { find out more about them. }\end{array}$ \\
\hline Intrapersonal & self-awareness, self-discovery & $\begin{array}{l}\text { Write about what you want to be in future. Describe } \\
\text { yourself (How do you look like?). Write fruits and } \\
\text { vegetables you like the most. }\end{array}$ \\
\hline Naturalist & natural environment & $\begin{array}{l}\text { Look outside the classroom window. What's the } \\
\text { weather like? }\end{array}$ \\
\hline
\end{tabular}

